\title{
HARMONISASI PERATURAN DAERAH KABUPATEN/KOTA PASCA PUTUSAN MAHKAMAH KONSTITUSI NOMOR 137/PUU-XIII/2015
}

\author{
Muhammad Roqib, S.H., M.H., ${ }^{1}$ \\ Fakultas Hukum Universitas Muhammadiyah Gresik \\ Muhammadroqib.umg@gmail.com
}

\begin{abstract}
Constitutional Court has issued Verdict No. 137/PUU-XIII/2015 about withdrawing the Governor's authority in cancelling regency/city regulation. The Constitutional Court has tested Article No. 251 (2), (3), (4), and (8) on the Constitution No. 23 of 2014 about Local Government. By this verdict, the only way to issue the cancellation of the regency/city regulation is through judicial review mechanism of Supreme Court (MA). Only after the Governor's authority in cancelling the regency/city regulation has been revoked, a problem appears in how to ensure the harmonization between the regency/city regulation and another regulation. This research uses statute approach, examining all of the constitutions with examined law issues and conceptual approach which starts from points of view and developing doctrines in science of law. Based on this research result, it is discovered that during the implementation of the Verdict of the Constutional Court No. 137/PUU-XIII/2015 did not deprive the control of central government towards local government, including the establishment of regency/city regulation. Governor as representative of central government in the region was given an authority to supervise preventively towards the establishment of regency/city regulation. By maximum preventive supervision, it would harmonize between regency/city regulation and another constitutional regulation.
\end{abstract}

Key Word(s) : Verdict of the Constitutional Court No. 137/PUU-XIII/2015, authority to cancel the local regulation, supervision of the local regulation formulization, harmonization between the regency/city regulation and another constitutional regulation.

\section{Latar Belakang}

Mahkamah Konstitusi telah mengeluarkan putusan Nomor 137/PUU-XIII/2015 tanggal 5 April 2015. Putusan itu mencabut kewenangan Gubernur membatalkan peraturan daerah (Perda) kabupaten/kota dan Menteri Dalam Negeri (Mendagri) membatalkan peraturan daerah provinsi. Mahkamah Konstitusi menguji Pasal 251 ayat (2), ayat (3), ayat (4), dan ayat (8) UndangUndang Nomor 23 Tahun 2014 tentang Pemerintahan Daerah.

\footnotetext{
${ }^{1}$ Dosen pada Prodi Hukum Fakultas Hukum Universitas Muhammadiyah Gresik
} 
Mahkamah Konstitusi menyatakan bahwa pencabutan peraturan daerah kabupaten/kota oleh Gubernur sebagai perwakilan pemerintah pusat di daerah bertentangan dengan UndangUndang Dasar Negara Republik Indonesia Tahun 1945. Hakim Mahkamah Konstitusi menyatakan bahwa pengujian atau pembatalan peraturan daerah merupakan ranah kewenangan konstitusional Mahkamah Agung (MA).

Dalam pertimbangan hukumnya, Mahkamah menyatakan bahwa :

Dalam perspektif negara kesatuan (unitary state, eenheidstaat) adalah logis untuk mengembangkan pengertian bahwa pemerintahan atasan berwenang melakukan control terhadap unit pemerintahan bawahan. Artinya, pemerintahan pusat dalam konteks NKRI berdasarkan UUD 1945 tentu dapat dikatakan mempunyai kewenangan untuk mengontrol unit-unit pemerintahan daerah provinsi ataupun pemerintahan daerah kabupaten/kota. Demikian pula pemerintahan daerah provinsi juga dapat diberi kewenangan tertentu dalam rangka mengendalikan jalannya pemerintahan daerah kabupaten/kota di bidang pengaturan. Yang dikendalikan atau dikontrol oleh pemerintahan itu antara lain misalnya melalui kewenangan untuk melakukan "executive abstract preview", bukan mekanisme "review" atas peraturan daerah yang sudah berlaku mengikat untuk umum. Oleh karena itu, terhadap peraturan daerah sebagai produk legislatif di daerah, sebaiknya hanya di "preview" oleh pemerintahan atasan apabila statusnya masih sebagai rancangan peraturan daerah yang belum mengikat untuk umum. Jika peraturan daerah itu sudah mengikat umum, maka sebaiknya yang mengujinya adalah lembaga peradilan sebagai pihak ketiga yang sama sekali tidak terlibat dalam proses pembentukan peraturan daerah yang bersangkutan sesuai dengan sistem yang dianut dan dikembangkan menurut UUD 1945 yakni "centralized model of judicial review", bukan "decentralized model", seperti ditentukan dalam Pasal 24A ayat (1) dan Pasal 24C ayat (1) UUD 1945 . $^{2}$

Sebelumnya, berdasarkan Undang-Undang Nomor 23 Tahun 2014 tentang Pemerintahan Daerah, wewenang executive review dimiliki oleh Gubernur dalam membatalkan peraturan daerah kabupaten/kota dan Menteri Dalam Negeri mempunyai wewenang membatalkan peraturan daerah provinsi. Kewenangan tersebut pada dasarnya sudah dimiliki pemerintah sejak era Orde Baru melalui Undang-Undang Nomor 5 Tahun 1974 tentang Pokok-Pokok Pemerintahan Daerah hingga pada masa Reformasi melalui Undang-Undang Nomor 22 Tahun 1999 tentang Pemerintahan Daerah, Undang-Undang Nomor 32 Tahun 2004 tentang Pemerintahan Daerah, dan Undang-Undang Nomor 23 Tahun 2014 tentang Pemerintahan Daerah. Namun, setelah sekian lama pemerintah mengemban wewenang tersebut, kini

\footnotetext{
2 Putusan Mahkamah Konstitusi Nomor 173/PUU-XIII/2015, tanggal 5 April 2015.
} 
pembatalan peraturan daerah hanya dimiliki lembaga yudisial semata yakni Mahkamah Agung (MA).

Menurut Undang-Undang Nomor 12 Tahun 2011 juncto Undang-Undang Nomor 15 Tahun 2019 tentang Perubahan Atas UU Nomor 12 Tahun 2011 tentang Pembentukan Peraturan Perundang-undangan disebutkan bahwa peraturan daerah adalah salah satu bentuk peraturan perundang-undangan dengan hierarki di bawah undang-undang. Sepanjang suatu norma hukum dituangkan dalam bentuk peraturan sebagaimana dimaksud dalam undang-undang tersebut dan tingkatannya berada di bawah undang-undang, maka sebagaimana ditentukan oleh Pasal 24A ayat (1) UUD NRI Tahun 1945, pengujiannya hanya dapat dilakukan oleh Mahkamah Agung, bukan oleh lembaga lain.

Pada prinsipnya ketentuan pengaturan dalam peraturan daerah yang akan mengejawantahkan urusan pemerintahan di daerah. Dalam perkembangan pelaksanaan otonomi daerah sekalipun dianut prinsip otonomi luas, keberadaan Perda yang strategis tersebut belum dapat diaktualisasikan sebagaimana mestinya. Perda yang diterbitkan sepanjang pelaksanaan otonomi luas sejak tahun 2001 senantiasa menjadi sorotan. Kondisi ini disebabkan karena implementasi wewenang mengatur daerah dalam bentuk Perda dipandang belum mencerminkan tujuan diberikannya otonomi luas. ${ }^{3}$ Hal ini ditunjukkan dengan bermunculannya Perda bermasalah dan dibatalkan. Sepanjang tahun 2001-2009 terdapat sebanyak 3.091 Perda bermasalah. ${ }^{4}$ Pemerintah menargetkan untuk menyelesaikan pembatalan sekitar 3.000 Perda bermasalah hingga akhir tahun 2010. Tahun 2016 Kementerian Dalam Negeri mengeluarkan kembali daftar Perda yang dibatalkan atau direvisi sebanyak 3.143 Perda. Kemudian tahun 2019 Kemendagri diminta kembali untuk melakukan penertiban terhadap Perda yang bermasalah. ${ }^{5}$

Munculnya kasus pembatalan Perda tersebut tidak dapat dilepaskan dari ketidakjelasan dan ketidakkonsistenan materi muatan pengaturan dalam Perda yang bersumber pada penggunaan wewenang mengatur oleh daerah otonom. Masih sering ditemukan adanya peraturan daerah yang tidak harmonis atau sinkron dengan peraturan perundang-undangan yang lebih tinggi, melanggar kepentingan umum, kesusilaan dan bahkan hak asasi manusia. Berdasarkan

\footnotetext{
${ }^{3}$ Enny Nurbaningsih, Problematika Pembentukan Peraturan Daerah, Aktualisasi Wewenang Mengatur di Era Otonomi Luas, Cet. I, PT RajaGrafindo Persada, Depok, 2019, h.1

${ }^{4}$ Ibid.

${ }^{5}$ Ibid.
} 
latar belakang di atas, maka yang akan menjadi isu hukum dalam artikel ini adalah bagaimana memastikan harmonisasi peraturan daerah kabupaten/kota dengan peraturan perundangundangan lainnya pasca putusan Mahkamah Konstitusi Nomor 137/PUU-XIII/2015.

\section{Analisa dan Pembahasan}

Dalam UUD 1945 sebelum perubahan tidak ada suatu ketentuan pun yang mengatur mengenai peraturan daerah. Dengan hanya mendasarkan pada satu pasal saja yakni Pasal 18 UUD 1945 yang mengatur tentang pemerintahan daerah akan sangat sulit memahami ruang lingkup pembentukan peraturan daerah karena kebijakan penyelenggaraan pemerintahan daerah sepenuhnya ditentukan lebih lanjut dalam Undang-Undang Pemerintahan Daerah.

Pengaturan Perda dalam konstitusi baru terakomodasi setelah perubahan UUD 1945. Dengan adanya perubahan Pasal 18 UUD 1945, kedudukan Perda sebagai salah satu jenis peraturan perundang-undangan menjadi kuat. Terkait dengan muatan Perda, secara tidak langsung disebutkan dalam ketentuan Pasal 18 ayat (6) UUD 1945 bahwa "Pemerintahan daerah berhak menetapkan peraturan daerah dan peraturan-peraturan lain untuk melaksanakan otonomi dan tugas pembantuan".

Pelaksanaan otonomi yang dimaksudkan dalam UUD tersebut berkaitan dengan urusan pemerintahan. Dengan demikian, lingkup materi muatan yang menjadi wewenang daerah untuk mengatur adalah segala sesuatu urusan pemerintahan yang telah ditetapkan oleh undang-undang sebagai kewenangan daerah. Urusan tersebut hanya untuk urusan yang telah didesentralisasikan. Bahkan, UUD NRI Tahun 1945 telah menegaskan asas otonomi dalam penyelenggaraan urusan yang didesentralisasikan. Artinya, dengan diterapkannya asas tersebut masing-masing daerah dapat mengembangkan kondisi riil daerahnya. Hal ini sesuai dengan prinsip otonomi yang dianut dalam hukum positif. Hanya saja selama ini dianutnya prinsip tersebut lebih bersifat proforma sehingga tidak pernah mampu terwujud dengan baik, akibatnya berdampak pada sistem pembentukan Perda yang berlangsung sangat ketat tanpa memberikan ruang kemandirian bagi masyarakat dalam mengembangkan kebutuhan daerah sesuai dengan kondisi riilnya. ${ }^{6}$

\footnotetext{
${ }^{6}$ Ibid., h.249.
} 
Untuk menjamin agar tidak terulang kondisi pengaturan dalam Perda yang hanya berfungsi sebagai instrumen hukum penguatan kepentingan pusat di daerah, perubahan UUD 1945 menentukan dengan tegas bahwa masing-masing daerah otonom mengatur dan mengurus sendiri urusan pemerintahannya dengan asas otonomi bagi urusan yang telah diserahkan dan dengan asas tugas pembantuan bagi urusan pusat atau daerah yang lebih tinggi yang dimintakan bantuan pengurusannya kepada daerah yang lebih rendah. Lebih lanjut, perubahan UUD 1945 menghendaki adanya pengakomodasian aspek kekhususan dalam pelaksanaan otonomi luas.

Dengan menekankan Perda dibentuk untuk melaksanakan segala ihwal yang menyangkut otonomi dan tugas pembantuan dimaksudkan agar dapat mendorong ke arah terwujud kesejahteraan masyarakat karena pemerintah daerah yang dianggap lebih tahu kebutuhan terkait di daerah. Konsekuensinya undang-undang beserta berbagai peraturan pelaksanaan yang kemudian lahir sebagai bentuk pelaksanaan dari pengaturan urusan pemerintahan tertentu seharusnya tidak boleh melampaui kewenangan Pasal 18 UUD 1945 dengan menyempitkan batas pengaturan Perda untuk melaksanakan otonomi. Tidak ada lagi alasan yang rasional untuk mengatakan bahwa pelaksanaan otonomi luas merupakan salah bentuk "ancaman terhadap NKRI", karena penggunaan wewenang mengatur daerah secara konstitusional adalah untuk menguatkan integritas NKRI.

Dalam kamus besar Bahasa Indonesia 2013 disebutkan bahwa harmonisasi berasal dari kata harmoni yang berarti upaya untuk mencari keselarasan (Kamus Besar Bahasa Indonesia : 2013). Menurut J.M. Sinclair, dalam Collin Cobuild Dictionary (1991) ditemukan kata harmonious dan harmonize dengan penjelasan sebagai berikut $:^{7}$ A relationship, agreement etc. that is harmonius is friendly and peaceful. Things which are harmonius have parts which make up an attractive whole and which are in proper proportion to each other. When people harmonize, they agree about issues or subjects in a friendly, peaceful ways; suitable, reconcile. If you harmonize two or more things, they fit in with each other is part of a system, society etc (Sinclair, 1991). ${ }^{8}$

\footnotetext{
${ }^{7}$ Soegiyono, "Pentingnya Harmonisasi Pembentukan Peraturan Perundang-undangan", Pusat Pengkajian dan Informasi Kedirgantaraan Lembaga Penerbangan dan Antariksa Nasional," 2015, https://puskkpa.lapan.go.id, h.8, diakses pada 25 November 2020.

8 Ibid.
} 
Unsur-unsur yang dapat ditarik dari perumusan pengertian harmonisasi tersebut di atas, yakni (i) adanya hal-hal yang bertentangan; (ii) menyelaraskan hal-hal yang bertentangan secara proporsional agar membentuk suatu sistem; (iii) suatu proses atau suatu upaya untuk merealisasi keselarasan, kesesuaian, keserasian, kecocokan, dan keseimbangan; (iv) kerjasama antara berbagai faktor yang sedemikian rupa, hingga faktor-faktor tersebut menghasilkan kesatuan yang luhur. 9

Dalam Undang-Undang Nomor 12 Tahun 2011 tentang Pembentukan Peraturan Perundang-undangan diatur mengenai sistem peraturan perundang-undangan yang tersusun secara hierarki. Adanya hierarki perundang-undangan tersebut adalah untuk memastikan adanya harmonisasi. Maksud dari pengharmonisasian peraturan perundang-undangan adalah sebagai upaya untuk menyelaraskan, menyesuaikan, memantapkan dan membulatkan konsepsi suatu rancangan peraturan perundang-undangan, termasuk di dalamnya rancangan peraturan daerah, dengan peraturan perundang-undangan baik yang lebih tinggi, sederajat, maupun yang lebih rendah, dan hal-hal lain selain peraturan perundang-undangan, sehingga tersusun secara sistematis, tidak saling bertentangan atau tumpang tindih. Hal ini merupakan konsekuensi dari adanya hierarki peraturan perundang-undangan (Setyadi, 2009). ${ }^{10}$

Harmonisasi peraturan perundang-undangan, termasuk di dalamnya peraturan daerah, adalah proses yang diarahkan untuk menuju keselarasan dan keserasian antara satu peraturan perundang-undangan dengan peraturan perundang-undangan lainnya sehingga tidak terjadi tumpang tindih, inkonsistensi atau konflik/perselisihan dalam pengaturan. Dalam kaitannya dengan sistem hierarki peraturan perundang-undangan, maka proses tersebut mencakup harmonisasi semua peraturan perundang-undangan termasuk peraturan daerah baik secara vertikal maupun horisontal. ${ }^{11}$

\footnotetext{
${ }^{9}$ Ibid.

10 Ibid.

${ }^{11}$ Muhammad Sapta Murti," Harmonisasi Peraturan Daerah dengan Peraturan Perundang-undangan lainnya ", http://ditjenpp.kemenkumham.go.id/htn-dan-puu/422, diakses pada 25 November 2020.
} 
Berkenaan dengan ketentuan pembatalan Perda yang termaktub dalam Pasal 251 UndangUndang Nomor 23 Tahun 2014 telah diajukan pengujian ke Mahkamah Konstitusi dan diputus oleh Mahkamah Konstitusi dalam Putusan Nomor 137/PUU-XIII/2015 tanggal 5 April 2015. Bertolak dari Putusan Mahkamah Konstitusi yang diikuti dengan putusan yang lain yakni Putusan Nomor 56/PUU-XIV/2016 maka Menteri Dalam Negeri dan Gubernur sebagai wakil pemerintah pusat tidak lagi memiliki kewenangan untuk melakukan pembatalan Perda. Jika pembatalan dimaksud tetap dilakukan dengan menerbitkan produk pembatalan berupa keputusan Mendagri justru akan menimbulkan ketidakpastian hukum akibat kemungkinan adanya dualisme putusan dari dua lembaga peradilan, sebagaimana hal tersebut pun telah dipertimbangkan oleh Mahkamah Konstitusi bahwa :

"Dalam hal Perda Kabupaten/Kota dibatalkan melalui keputusan gubernur upaya hukum yang dilakukan adalah melalui Pengadilan Tata Usaha Negara (PTUN) dan seandainya upaya hukum tersebut dikabulkan maka Perda Kabupaten/Kota yang dibatalkan oleh keputusan gubernur menjadi berlaku kembali. Di sisi lain, terdapat upaya hukum pengujian Perda melalui Mahkamah Agung yang dilakukan oleh Pemerintah, masyarakat di daerah tersebut atau pihak yang merasa dirugikan dengan berlakunya Perda tersebut. Misalnya upaya hukum melalui Mahkamah Agung tersebut dikabulkan maka Perda menjadi dinyatakan tidak berlaku. Dengan demikian telah terjadi dualisme dalam persoalan yang sama. Potensi dualisme putusan pengadilan antara putusan PTUN dan putusan pengujian Perda oleh Mahkamah Agung terhadap substansi perkara yang sama, hanya berbeda produk hukum akan menimbulkan ketidakpastian hukum, padahal kepastian hukum merupakan hak setiap orang yang dijamin dan dilindungi oleh Pasal 28D ayat (1) UUD 1945. Oleh karena itu, demi kepastian hukum dan sesuai dengan UUD 1945 menurut Mahkamah pengujian atau pembatalan Perda menjadi ranah kewenangan konstitusional Mahkamah Agung". ${ }^{2}$

Dengan adanya Putusan Mahkamah Konstitusi Nomor 137/PUU-XIII/2015 yang telah membatalkan kewenangan Mendagri dan Gubernur melakukan pengawasan represif yang diwujudkan dalam bentuk pembatalan Perda maka mengharuskan pemerintah pusat menguatkan pengawasan preventif terhadap proses pembentukan Perda. Sebelumnya, pemerintah melakukan berbagai upaya pembinaan legislasi daerah dengan menerbitkan aneka produk hukum, tidak hanya dalam bentuk peraturan pemerintah tetapi juga surat edaran sebagai salah satu bentuk beleidsregel. Dengan adanya putusan MK Nomor 137/PUU-XIII/2015 disusul kemudian dengan putusan MK Nomor 56/PUU-XIV/2016 mengharuskan pemerintah dalam hal ini Mendagri dan Gubernur sebagai wakil pemerintah pusat memaksimalkan upaya harmonisasi peraturan daerah sebagai bentuk pengawasan preventif agar terbentuk perda yang harmonis dengan peraturan

\footnotetext{
12 Putusan Mahkamah Konstitusi Nomor 137/PUU-XIII/2015, tanggal 5 April 2015
} 
perundang-undangan lainnya, tidak tumpang tindih, dan tidak terjadi konflik/perselisihan dalam pengaturan. Pemerintah sejak awal dituntut melakukan pembinaan dan melakukan "executive abstract preview" terhadap semua rancangan peraturan daerah kabupaten/kota yang diajukan untuk disahkan.

\section{Kesimpulan}

Dengan adanya putusan Mahkamah Konstitusi Nomor 137/PUU-XIII/2015 yang menyatakan bahwa kewenangan Menteri Dalam Negeri dan Gubernur selaku wakil Pemerintah Pusat dalam membatalkan peraturan daerah kabupaten/kota inkonstitusional atau bertentangan dengan UUD NRI Tahun 1945, maka dalam pengujian terhadap perda kabupaten/kota hanya Mahkamah Agung yang berwenang mengujinya.

Kewenangan pemerintah pusat dalam hal ini Gubernur terhadap perda kabupaten/kota hanya sebatas pengawasan secara preventif yakni pemberlakuan tiap peraturan daerah yang mengatur persoalan-persoalan tertentu, terlabih dahulu mendapatkan persetujuan Gubernur selaku wakil pemerintah pusat di daerah. Pengawasan yang dilakukan oleh Gubernur terhadap pembentukan perda kabupaten/kota lebih ditekankan pada pemeriksaan materi muatan yang lebih ketat (double check) pada saat permohonan nomor register.

Pemeriksaan materi muatan itu berkaitan dengan apakah sesuai dengan peraturan perundang-undangan yang lebih tinggi, kepentingan umum, atau kesusilaan. Jika pemerintah kabupaten/kota tidak menindaklanjuti hasil dari evaluasi atau fasilitasi rancangan perda yang dilakukan oleh Gubernur, maka nomor register perda tidak akan diberikan sehingga perda tersebut tidak dapat diundangkan. Dengan pengawasan preventif yang maksimal maka akan tercipta harmonisasi perda kabupaten/kota dengan peraturan perundang-undangan lainnya.

Dengan adanya putusan Mahkamah Konstitusi Nomor 137/PUU-XIII/2015 maka seharusnya Pemerintah segera merevisi Pasal 252 dan Pasal terkait lainnya dari Undang-Undang Nomor 23 Tahun 2014 tentang Pemerintahan Daerah. Dengan begitu, ketentuan Pasal 252 dan Pasal terkait lainnya dari UU 23/2014 yang memberlakukan ketentuan sanksi terhadap daerah bisa berlaku efektif. 


\section{DAFTAR PUSTAKA}

\section{Buku - buku}

Ahmad Redi.2018. Hukum Pembentukan Peraturan Daerah, Jakarta : Sinar Grafika.

Bagir Manan.2001. Menyongsong Fajar Otonomi Daerah, Yogyakarta : Pusat Studi Hukum UII.

Enny Nurbaningsih. 2019. Problematika Pembentukan Peraturan Daerah, Jakarta : RajaGrafindo Persada.

\section{Website}

https://puskkpa.lapan.go.id, h.8, "Pentingnya Harmonisasi Pembentukan Peraturan Perundangundangan", diakses pada 25 November 2020 .

http://ditjenpp.kemenkumham.go.id/htn-dan-puu/422, "Harmonisasi Peraturan Daerah dengan Peraturan Perundang-undangan lainnya," diakses pada 25 November 2020.

\section{Daftar Peraturan Perundang-Undangan}

Undang-Undang Dasar Negara Republik Indonesia Tahun 1945

Undang-Undang Nomor 23 Tahun 2014 tentang Pemerintahan Daerah sebagaimana telah diubah beberapa kali dan terakhir dengan Undang-Undang (Lembaran Negara Republik Indonesia Tahun 2014 Nomor 244, Tambahan Lembaran Negara Republik Indonesia Nomor 5587)

Undang-Undang Nomor 9 Tahun 2015 tentang Perubahan Kedua Atas Undang-Undang Nomor 23 Tahun 2014 tentang Pemerintahan Daerah. (Lembaran Negara. Republik Indonesia Tahun 2015 Nomor 24)

Undang-Undang Nomor 12 Tahun 2011 tentang Pembentukan Peraturan Perundang-Undangan (Lembaran Negara Republik Indonesia Tahun 2011 Nomor 82, Tambahan Lembaran Negara Republik Indonesia Nomor 5234) 
Undang-Undang Nomor 15 Tahun 2019 tentang Perubahan Atas Undang-Undang Nomor 12 Tahun 2011 tentang Pembentukan Peraturan Perundang-Undangan (Lembaran Negara Republik Indonesia Tahun 2019 Nomor 183, Tambahan Lembaran Negara Republik Indonesia Nomor 6398).

\section{Putusan}

Putusan Mahkamah Konstitusi Nomor 137/PUU-XIII/2015

Putusan Mahkamah Konstitusi Nomor 56/PUU-XIV/2016 